\title{
Implementation of Transformational Leadership Style in Improving the Quality of Institutions
}

\author{
Desi Eri Kusumaningrum \\ Department of Educational Administration \\ Universitas Negeri Malang \\ desieri.fip@um.ac.id
}

\author{
Erika Mei Budiarti \\ Department of Educational Administration \\ Universitas Negeri Malang \\ meierika09@gmail.com
}

\begin{abstract}
One of the biggest problems faced by educational institutions is a crisis of trust in society because the quality of these institutions is included in the low category. The role of the principal in this case must be in accordance with the duties, authority, and overall responsibility. The purpose of this study is to find out transformational leadership can support the realization of quality educational institutions and examine further related factors supporting and inhibiting them. The data in this study were obtained by interview, observation and documentation study. Based on the analysis, the results show that: (1) the application of transformational leadership style in Vocational School (SMK) Dwija Bhakti 2 Jombang; and (2) strategies for improving the quality of educational institutions through transformational leadership styles at SMK Dwija Bhakti 2 Jombang.
\end{abstract}

Abstract: transformational leadership style, quality of institutions

\section{INTRODUCTION}

One of the things that is always interesting to study is related to the leadership of an organization. One organization that is also interesting to discuss is the educational organization. Speaking related to leadership in educational institutions, the role of a leader is always attached to the quality of the institution being led. Quality is the overall characteristics or characteristics of the product or service in order to meet the needs and expectations of customers (Ariani: 2003). The presence of a school principal who truly has managerial skills is very important, so that all resources owned by the school can be optimally empowered in order to improve the quality of the institution.

In relation to the quality / quality of an institution, many factors affect its achievement. Among them are the quality of teachers, facilities and infrastructure, the quality of students and their input, and the quality of community involvement in all school activities. The low quality of this school can affect the image of the school in the eyes of the community. As is the case in the Dwija Bhakti 2 Vocational School in recent years, the image of this institution is underestimated by the surrounding community. Many people consider that Dwija Bhakti 2 Vocational School is only limited to "outcast" schools, meaning that it is only for students who tend to behave negatively and have low academic and non-academic abilities (who do not qualify for the selection of new students in state schools), and a place for undisciplined students. Such a view of the institution has existed for years in the community.

Until in the end the negative image judged by the community for institutions gradually eroded. The erosion of these negative views can begin to be felt since 2016 . Starting in 2016 until now, the institution has gradually improved and began to show its existence among state and private senior secondary schools. This is shown by the increasing discipline of teachers and students, a number of academic and non-academic achievements have begun to be obtained by institutions, so that interested students (prospective students) who want to enter SMK Dwija Bhakti 2 in recent years. Some of these things can be highlighted as an improvement in the quality of the institution.

Positive changes that occur at the institution can not be separated from the strategies or ways implemented by schools specifically to minimize the public's view of the negative implementation of education in SMK Dwija Bhakti 2. Through preliminary studies obtained by researchers of several staff (employees) and teachers who work at the institution That, the strategy or effort carried out over the last few years is on the principal. The principal has full authority to lead the institution, and the way this is done is through a form of communication to all employees through the adoption of a transformational leadership style. According to (Burns, 1978) stated that "transformational leadership occurs when leaders and followers raise one another to higher levels of values and motivations." It can be interpreted that transformational leadership occurs when leaders and followers increase each other to the level of values and motivation that higher.

While according to Bass (in Rahmi and Umiarso, 2016) there are at least 4 (four) components that are absolutely owned by transformative leaders. The first component is the ideal influence which means that a leader should be able to provide positive influences that lead to the vision to be achieved by the institution. The second component is inspirational motivation, which means that a leader must always be able to give enthusiasm to all employees so that they are never bored and always maintain the spirit of working in order to realize the expectations to be achieved so that all stakeholders move in utilizing the slightest opportunity through creative ideas for the progress of the institution. The third component is intellectual stimulation, in this context the leader must be able to provide stimuli to all employees to be alert and intelligent in overcoming various personal and institutional problems. The fourth component is individual consideration, which means that transformative leaders constantly reflect, think, and continuously identify the needs of their employees, recognize the competencies of each member in the institution being led, delegate authority, and provide intensive guidance and attention to all members to achieve the goals the institution. 
A transformative school principal is needed in an institution in order to make positive changes both small and large scale. This is because the headmaster who has the type of transformational leadership is in line with efforts to achieve quality (quality) that must be carried out by all stakeholders in the institution through command, direction, and good communication from the principal as the leader of the institution to his employees. As is the case in the Dwija Bhakti 2 Vocational School in the past few years which is considered capable of making changes in a positive direction, this condition is considered unique because schools are able to overcome problems related to the implementation of their education, so researchers consider that it is necessary to conduct in-depth research in SMK Dwija Bhakti 2 related to problem solving strategies undertaken by the principal so that it was found that since 2016 until now the institution was able to transform from the quality of institutions that were considered poor to be institutions that had good quality so that the institution could display a positive image in the eyes of the community.

\section{Quality of Educational Institutions}

II. THEORITICAL REVIEW

Danim (2007) states that quality in education leads to inputs, processes, outputs and outcomes. Input quality is seen from several sides. First, whether the conditions are good or not human resources (principals, teachers, laboratory assistants, administrative staff, and students). Second, whether or not the material input criteria are met in the form of teaching aids, books, curriculum, school facilities and infrastructure. Third, fulfill or not input in the form of software, such as regulations, organizational structure, and job descriptions. The four input qualities are expectations and needs such as vision, mission, motivation, perseverance, and ideals.

Komariah and Triatna (2008) suggested that the quality / quality of schools can be identified from the number of students who have achievements, both academic achievements and other field achievements and graduates relevant to the objectives. Through students who excel can be traced to the management of their schools, the profiles of their teachers, their learning resources, and their environment. Thus the quality of the school reflects customer satisfaction, active participation from management in the process of continuous quality improvement, the understanding of each person towards responsibilities specific to quality, each individual in the school and stakeholders is aware of and realizes the principle of "preventing damage" and carry out the view of quality as a way of life (way of life).

Fadjar (1998) explained that efforts to improve the quality of academic-oriented education can be pursued through the following methods, namely: (a) quality assurance to all educational institutions so as to accelerate students to be filtered when quality control is carried out through national examinations; (b) ensuring the welfare of the teaching staff so that they can live properly and be able to focus their attention on teaching activities; (c) encourage regions and institutions to be able to mobilize various sources of funds in order to improve the quality of education services. In addition to these methods, Nurkholis (2003) explained that the quality of education can also be improved through several ways such as (a) increasing the size of academic achievement through national exams or regional examinations concerning competency and knowledge, improving talent tests, competency certification and portfolio profiles; (b) forming peer groups to increase the passion for learning through cooperative learning; (c) creating new opportunities at school by turning school hours into centers of learning throughout the day and keeping schools open during holiday hours; (d) increase understanding and appreciation of learning through mastery of material and appreciation for academic achievement; (e) help students find work by offering courses related to job acquisition skills.

As according to Sudrajat (2005) quality in education has the definition of two aspects, namely: (a) measurement of the ability of graduates in accordance with the school goals set in the curriculum; (b) measurement of meeting the needs and demands of customers, namely parents of students and the community. Orientation on quality is very important for an organization or educational institution. There are several reasons why the quality of an educational institution is very important, namely (a) increasing the reputation of the organization; (b) reduce costs; (c) increase market prey; (d) international impacts; (e) product accountability; (f) for product appearance; and (g) realizing quality that is felt to be important.

It can be concluded that quality in educational institutions has characteristic characteristics compared to quality in the industrial world. This distinctive difference is in the product produced. In the industrial world the quality produced is in the form of goods that can be measured systematically, while in educational institutions the quality produced is in the form of services. There are two educational institution service users, namely internal and external. Internal parties are teachers and students. While external users are parents, the community and the world of work. Both users of educational services must receive serious attention by education providers because the quality of a good educational institution is able to meet all forms of needs, expectations, and desires of all users. While in this case the users who are the focus of attention are learners (students). Students are the main reason for education, and students also cause the existence of educational institutions and systems.

Another thing related to the essence of the quality of educational institutions is the main factors in order to improve the quality of education in a school. Danim (2007) said that if an institution / institution wants to improve the quality of its education the school must involve several dominant factors, namely: (a) the principal's leadership; (b) teacher; (c) students / students; (d) curriculum; and (e) cooperation network. Principal's leadership means that the principal must have and understand a clear work vision, be able and willing to work hard, have a high work motivation, be persistent and steadfast in working, provide optimal service, and strong work discipline. Next is the teacher, which is the maximum involvement of teachers by increasing the competence and professional work of teachers in seminars, workshops, and training so that the results of these activities are determined at school. Next is the students / students, where the approach that must be taken is the child as the center so that students' competencies and abilities can be explored so that the 
school can understand the strengths and weaknesses of the students. Next is a curriculum that is consistent, dynamic, and integrated that can enable and facilitate the expected quality standards so that goals can be achieved to the maximum. The next factor is the network of cooperation that is not only limited to the school and community environment but with other organizations such as companies or government agencies so that the output of schools can be absorbed in the world of work quickly and accurately.

\section{Transformational Leadership Education}

Siagian (2003) leadership is the motor or driving force of all sources and tools available to an organization. Marno and Supriyatno (2008) leadership is defined as an effort to influence a group in certain situations, certain times and a set of environments aimed at encouraging people to try to achieve goals. Wahyudi (2009) leadership is defined as the ability of a person to move, direct, and at the same time influence the mindset, the workings of each member to be independent in working, especially in making decisions in the interests of accelerating the achievement of established goals. Some definitions of leadership can be reformulated that leadership is about leading. While leadership is a broad phenomenon that is an action taken by a person (individual) as a leader in order to take the initiative to influence, invite, give direction, and motivation to employees (individuals or groups) in order to complete tasks and work that lead to the achievement of goals- goals set by the organization / institution. When linked to education, educational leadership is the ability of a head of an educational institution in order to take initiatives to influence, direct, motivate, coordinate and mobilize its employees to achieve educational goals (teaching, learning, and administration) effectively and efficiently.

Soetopo and Soemanto (1988) leaders who want to achieve the progress of their school education programs must realize that good human relations are an important foundation in their leadership. So that from the exposure it was found that it is very important for the principal to realize the social relations created in the school environment need to be maintained conducive through effective multi-directional communication so that everything that will be communicated by the principal can be absorbed and carried out well by all employees.

One type of leadership deemed representative of the current demands of decentralization according to Komariah and Triatna (2008) is transactional leadership, transformational leadership, and visoner leadership. Transformational leadership is leadership that is able to build changes in the body of the organization in accordance with established values by empowering the whole community through directed communication so that followers can work more energetic and focused. More complex, Starrat (2007) and Burhanuddin (2005) explain that transformational leadership in education is defined as a leadership style that prioritizes the provision of opportunities that encourage all elements or elements of the school (teachers, students, staff / staff, parents, and surrounding communities) to work on the basis of a noble value system so that all elements in the school are willing to participate optimally in achieving the vision of the school so that it can invite people's attention to the main goals of the organization where the achievement of school objectives fully depends on the policies set by the principal of all school personnel. In line with the above opinion, Danim and Suparno (in Asmani, 2012) explained that transformational leadership patterns are one of the choices for principals to lead and develop quality schools.

The dimension of transformational leadership according to Bass and Avolio (in Komariah and Triatna: 2008) is known as the $4 \mathrm{I}$ concept, namely: idealiced influence, inspirational motivation, intellectual stimulation, and individualized consideration. Idealiced influence is a behavior that results in respect and confidence from the person they lead. This understanding also implies the sharing of risks through consideration of staffing needs above personal needs and ethical behavior ethically.

Inspirational motivation is reflected in behavior that always provides a challenge to the work done by staff and pay attention to the meaning of work for staff. Leaders demonstrate or demonstrate commitment to organizational goals through behavior that can be observed by staff. Leaders are motivators who are eager to continue to arouse the enthusiasm and optimism of staff.

Intellectual stimulation is a leader who practices innovations. His leadership attitude and behavior is based on developing science and intellectually able to translate in the form of productive performance. Leaders always explore creative ideas and solutions from staff and always encourage staff to learn and practice new approaches to doing work. Individualized consideration, namely the leader reflects himself as a person who is attentive in listening to and following up on complaints, ideas, expectations, and all input given by staff. Leaders pay special attention to the needs of achievement and the needs of the people they lead.

Bush and Coleman (2008) state about the need for transformational leadership to be applied in schools because: (a) it provides opportunities for subordinates to participate in the change process; (b) encourage subordinates to form social groups and build traditions of mutual support during the process of change; (c) opening up opportunities, positive feeback for all parties involved in the change; (d) sensitive to the outcomes of the development process and create conditions conducive to the feedback needed. While according to Epitropika (2001), there are six reasons why transformational leadership is important for an institution, because transformational leadership is considered to significantly improve organizational performance, positively associated with long-term marketing orientation and customer satisfaction, arousing the commitment of members to the organization, increasing workers 'trust in management and organizational daily behavior, increasing job satisfaction through work and leaders, and reducing workers' stress and increasing welfare.

Implementation of transformational leadership models in educational institutions is very necessary to pay attention to several aspects including referring to the religious values and ideology of the country, adjusted to the values contained in the relevant organizational or institutional system, as well as the cultural values that exist within the institution. Some of these aspects need to be 
considered because educational institutions are subsystems or part of a larger system above it such as a country's system.

\section{METHOD}

This study was designed using a qualitative research design as a stage of research and data collection. Based on the design of the research carried out, the presence of researchers is needed because the researcher acts as a key instrument of nature to explore in depth and detailed information. This research was conducted at SMK Dwija Bhakti 2 Jombang, which is in the middle of the city center of Jombang, East Java, Indonesia. The data source in this study uses primary data and secondary data. Primary data sources are several employees (teachers and administrative staff) who are under the leadership of the principal. Secondary data sources in the form of documentation which is then analyzed and used as supporting evidence.

Researchers use several techniques in general, namely interviews, observation, and documentation. The next activity is data analysis, using the stages of data reduction, data display, and data verification. Data reduction is a review in sorting out the data received according to existing field conditions. Data display is the result of a reduction arranged structured and displayed in the results of the study, while data verification is the stage of checking the compatibility of the meaning of the data obtained from the field to reach strong conclusions.

\section{RESULTS AND DISCUSSION} Implementation of Transformational Leadership in SMK Dwija Bhakti 2 Jombang

The image of the institution that was felt negatively by the community did not make the principal reduce his enthusiasm to lead for SMK Dwija Bhakti 2 Jombang. From 2015 until now, principals have begun to show a different leadership style in order to improve the image of the institution in a serious way in achieving the school goals to be achieved. The principal intensively conducts meetings and apples to all employees to be serious in doing work that is the responsibility of each employee.

In addition, school principals are also open when employees complain of workloads that are considered difficult or heavy. The open attitude shown by the headmaster is to give enthusiasm / motivation to work and try to help with the difficulties / complaints that are being felt by the staff so that the employee can feel that the headmaster also always gives attention to every employee. This form of attention can also be felt through close and effective communication between the principal and staff.

This intimacy can be seen from the gathering activities of the entire family of SMK Dwija Bhakti 2 Jombang. The agenda in this gathering activity is designed to foster employee morale, brainstorming positive ideas or innovations for the progress of the institution, having a close and serious communication session in the midst of providing material at the gathering, and giving opportunities to all members to express all the enthusiasm and ability to solve the challenges given at the time of the gathering and the completion of the gathering while at school.

Seeing this, the leadership of SMK Dwija Bhakti 2 Jombang's leadership is in line with the opinions of Bass and Avolio (in Komariah and Triatna, 2008) that transformational leadership applies the concept of $4 \mathrm{I}$, namely: (1) idealized influence reflected in the communication of the school principal to employees who always direct all actions (work ) which leads to the goals of the institution; (2) inspirational motivation is reflected in the attitude of the principal who always provides enthusiasm / motivation and positive influences to do the best work possible by maximizing all abilities; (3) intellectual stimulation in this case the principal provides opportunities (space and time) to all employees to brainstorm ideas or innovations that can be done for the progress of the institution; and (4) individual considerations that are reflected in behavior that tends to carry out actions that always absorb the aspirations of their subordinates, empower subordinates for existing work, accommodate all the needs felt by subordinates, and create an atmosphere of mutual trust, respect, sympathy, friendship, and always foster participation of all employees for all decisions to be taken so that what becomes the task is the result of joint decisions and can be done together as well as possible.

\section{Strategies for Improving the Quality of Educational Institutions through Transformational Leadership at SMK Dwija Bhakti 2 Jombang}

The principal's efforts in improving the quality of education in institutions led by the transformational leadership style adopted are by maintaining the trust of the public who have become customers and increasing the contribution / participation of all stakeholders by: (a) there is a strengthening program for student discipline guidance by provision of clear rules accompanied by consequences of violations if students do not participate in learning and extracurricular activities, there is a guidance and counseling program that is communicated with parents of students for students who have problems and those who have no problems; the existence of home visits from the teacher to students, as well as increasing the participation of students in competitions or competencies both locally, regionally, and nationally academically and nonacademically; (b) improving the quality of human resources through the inclusion of educators and education personnel in activities that are useful to improve their competence such as seminars, workshops, comparative studies, KKG, MGMP, and so on; the existence of a program to the house in order to establish intimacy between colleagues; the school principal gives permission to his staff to continue studying divided by time by work in the context of increasing employee competency; (c) the fulfillment of learning facilities for students by continuously working to improve and add buildings and fulfill other learning media by involving all employees and parents of students as a form of transparency in school financial reporting.

This is in line with the opinion of Danim and Suparno (in Asmani, 2012) that the principal's leadership pattern adopts a transformational style is one of the choices for principals to lead and has the potential to develop quality schools. Reinforced by Bush and Coleman (2008) that the strategy to improve the quality of institutions through transformational leadership is considered important to be implemented in schools and the efforts made by the head 
of SMK Dwija Bhakti 2 Jombang are in accordance with the reasons (a) the school principal gives the opportunity for employees to participate in change process; (b) the principal is able to encourage subordinates to form social groups and build traditions of mutual support during the process of change; (c) open opportunities for positive feedback for all parties involved in the change; (d) sensitive to the outcomes of the development process and create conditions conducive to the feedback needed.

\section{CONCLUSIONS}

Based on the research results obtained, it can be concluded that the head of SMK Dwija Bhakti 2 Jombang applies transformational leadership with the application of the $4 \mathrm{I}$ concept, namely idealized influence reflected in the principal's communication to employees who always direct all actions (jobs) that lead to the goals of the institution; Inspirational motivation is reflected in the attitude of the principal who always provides enthusiasm / motivation and positive influences to do the best work possible by maximizing all abilities; intellectual stimulation in this case the principal provides opportunities (space and time) to all employees to brainstorm ideas or innovations that can be done for the progress of the institution; and individual considerations that are reflected in behavior that tends to carry out actions that always absorb the aspirations of their subordinates, empower subordinates for existing work, accommodate all the needs felt by subordinates, and create an atmosphere of mutual trust, respect, sympathy, friendship, and always foster participation of all employees for all decisions to be taken so that what becomes the task is the result of joint decisions and can be done together as well as possible.

The principal's efforts in improving the quality of education in institutions led by the transformational leadership style adopted are by maintaining the trust of the public who have become customers and increasing the contribution / participation of all stakeholders by: (a) there is a strengthening program for student discipline guidance by provision of clear rules accompanied by consequences of violations if students do not participate in learning and extracurricular activities, there is a guidance and counseling program that is communicated with parents of students for students who have problems and those who have no problems; the existence of home visits from the teacher to students, as well as increasing the participation of students in competitions or competencies both locally, regionally, and nationally academically and nonacademically; (b) improving the quality of human resources through the inclusion of educators and education personnel in activities that are useful to improve their competence such as seminars, workshops, comparative studies, KKG, MGMP, and so on; the existence of a program to the house in order to establish intimacy between colleagues; the school principal gives permission to his staff to continue studying divided by time by work in the context of increasing employee competency; (c) the fulfillment of learning facilities for students by continuously working to improve and add buildings and fulfill other learning media by involving all employees and parents of students as a form of transparency in school financial reporting.

\section{REFERENCES}

[1] Ariani, D.W. 2003. Manajemen Kualitas: Pendekatan Sisi Kualitatif. Jakarta: Ghalia Indonesia.

[2] Burhanuddin, Y. 2005. Administrasi Pendidikan: untuk Fakultas Tarbiyah Komponen MKDK. Bandung: Pustaka Setia.

[3] Burns, J.M. 1978. Leadership, Harper \& Row. New York: NY.

[4] Bush, T. \& Coleman, M. Manajemen Strategis Kepemimpinan Pendidikan. Jogjakarta: IRCiSoD.

[5] Danim, S. (2010). Inovasi Pendidikan dalam Upaya Peningkatan Profesionalisme Tenaga Kependidikan. Bandung: CV. Pustaka Setia.

[6] Danim, S. 2007. Visi Baru Manajemen Sekolah. Jakarta: Bumi Aksara.

[7] Epitoprika, O. 2001. Kepemimpinan Transformasional Pendidikan. Bandung: Alfabeta.

[8] Fadjar, A. M. 1998. Madrasah dan Tantangan Modernitas. Bandung: Mizan.

[9] Komariah, A. \& Triatna, C. 2008. Visionary Leadership menuju Sekolah Efektif. Bandung: Alfabeta.

[10] Marno \& Supriyatno, T. 2008. Manajemen dan Kepemimpinan Pendidikan Islam. Bandung: Refika Aditama.

[11] Nurkholis. 2003. Manajemen Berbasis Sekolah, Teori, Model, dan Aplikasi. Jakarta: PT. Gramedia Widiasarana Indonesia.

[12] Rahmi, S. \& Umiarso. 2016. Manajemen Pendidikan dan Kepemimpinan Transformasional. Bandung: Remaja Rosdakarya.

[13] Siagian, S.P. 2003. Teori dan Praktik Kepemimpinan. Jakarta: Rineka Cipta.

[14] Soetopo, H. \& Soemanto, W. 1988. Kepemimpinan dan Supervisi Pendidikan. Jakarta: Bina Aksara.

[15] Starratt, R.J. 2007. Menghadirkan Pemimpin Visioner: Kiat Menegaskan Peran Sekolah. Yogyakarta: Kanisius.

[16] Sudrajat, H. 2005. Manajemen Peningkatan Mutu Berbasis Sekolah Peningkatan Mutu Pendidikan melalui Implementasi KBK. Bandung: Cipta Cekas Grafika.

[17] Wahyudi. 2009. Kepemimpinan Kepala Sekolah dalam Organisasi Pembelajar (Learning Organization). Bandung: Alfabeta. 